\title{
PENGEMBANGAN LABORATORIUM KEWIRAUSAHAAN TERPADU PRODI PENDIDIKAN EKONOMI
}

\author{
Wiedy Murtini, Sri Sumaryati, Leny Noviani \\ FKIP Universitas Negeri Surakarta \\ email : idik_53@yahoo.co.id
}

\begin{abstract}
Abstrak: Tujuan penelitian ini adalah untuk (1) menguji efektivitas prototipemodel laboratorium entrepreneurship terpadu di Program Studi Pendidikan Ekonomi melalui uji coba secara terbatas; (2) melakukan evaluasi dan revisi model; (3) uji coba secara lebih luas, model yang disarankan bagi upaya pengembangan ke depan. Pendekatan penelitian menggunakan research and development dengan dua tahapan penelitian. Pada tahap pertama telah dilakukan studi eksplorasi dan membuat prototipe model praktik kewirausahaan terpadu. Hasil penelitian tahap kedua adalah (1) uji coba rancangan model pada kelompok terbatas efektif ditunjukkan dengan kreativitas dan antusiasme serta keberhasilan tiga kelompok uji coba dalam menghasilkan dan menjual produk usaha. (2) Dari hasil evaluasi dan revisi, prototipe model pembelajaran praktik entrepreneurship terpadu dan model laboratorium entrepreneurship terpadu layak digunakan, revisi hanya pada teknis pelaksanaan. (3) Hasil uji coba model secara lebih luas, secara keseluruhan menyatakan model laboratorium entrepreneurship layak untuk digunakan dan diusulkan untuk dilaksanakan di Prodi pendidikan Ekonomi, PIPS, FKIP, UNS.
\end{abstract}

Kata Kunci: laboratorium kewirausahaan terpadu, entrepreneurship terpadu

\section{THE DEVELOPMENT OF THE INTEGRATED ENTREPRENEURSHIP LABORATORY OF THE ECONOMIC EDUCATION STUDY PROGRAM}

\begin{abstract}
The purposes of this study were: (1) to test the effectiveness of a prototype model of the integrated entrepreneurship laboratory in the Economic Education Department through a limited try out; (2) to evaluate and revise the model; (3) to try out the model in the wider contexts, the model suggested for future development efforts. The study used the research and development approach with 2 stages. In the first phase of the study, an exploration was carried out and an integrated entrepreneurship workshop model prototype was developed. The findings of the second stage of the study showed that: (1) the model was effective in the limited try out, indicated by the creativity, enthusiasm, and success of the three groups used in the try out in making and selling the product. (2) based on the result of the evaluation and revision, the integrated entrepreneurship workshop model prototype and the integrated entrepreneurship laboratory were appropriate to be used. The revision was done only in the technical implementation. (3) based on the result of the wider try out, the integrated entrepreneurship laboratory was appropriate to be used and it is suggested to be used in the Economic Education Study Program in PIPS, FKIP, UNS.
\end{abstract}

Keywords : integrated entrepreneurship laboratory, integrated entrepreneurship

\section{PENDAHULUAN}

Pada hakikatnya pendidikan adalah pembelajaran sepanjang hayat sehingga harus mampu membekali pebelajar dengan sesuatu yang bermakna agar dapat menjadi manusia yang bermanfaat bagi diri sendiri, keluarga, masyarakat, bangsa dan negara. Untuk menjadi manusia tangguh dan mampu bersaing di kancah perekonomian global, di mana persaingan semakin ketat, Program Studi (Prodi) Pendidikan
Ekonomi, PIPS, FKIP, UNS merasa perlu meningkatkan kemampuan praktik kewirausahaan atau entrepreneurship skill pada mahasiswa.

Pelaksanaan pembelajaran kewirausahaan pada tiga Bidang Keahlian Khusus (BKK) di Program Studi pendidikan ekonomi, yaitu BKK akuntansi, tata niaga, dan administrasi perkantoran, selama ini berjalan sendiri-sendiri, tidak terintegrasi dalam satu kegiatan kewirausahaan. Setiap BKK melaksanakan pembela- 
jaran kewirausahaan yang diampu oleh dosen yang berbeda, silabus yang berbeda, strategi dan model pembelajaran yang berbeda. Apabila program pembelajaran kewirausahaan di Prodi pendidikan ekonomi, melaksanakan kegiatan praktik pembelajaran kewirausahaan secara terpadu, terintegrasi dalam kegiatan laboratorium entrepreneurship dan bekerjasama dengan dunia usaha dan dunia industri (DUDI), maka akan terjalin kerjasama antar mahasiswa dari berbagai bidang keahlian, tercipta cross section learning dengan multidiplinary perspectives, dengan demikian akan terjadi transfer knowledge and experience antarmahasiswa, dosen dan entrepreneur. Dengan model pembelajaran seperti ini akan memperkuat pengembangan ide, dan inovasi usaha. Di samping itu, usaha untuk menanamkan, menumbuhkan, dan mengembangkan nilai-nilai karakter kewirausahaan diharapkan akan dapat tercipta dengan baik.

Pembelajaran kewirausahaan sebagai inisiasi awal untuk menumbuhkan jiwa wirausaha, memerlukan strategi pembelajaran yang dapat merangsang dan mendorong tumbuhnya jiwa wirausaha bagi para pebelajar. Kewirausaaan sebagai "science" dan "art" perlu perpaduan antara scientist dan practitionist, pendekatan pembelajaran secara teoretik perlu diperkuat dengan pembelajaran praktik.

Hasil diskusi kelompok terfokus dengan dosen pengampu mata kuliah kewirausahaan, pakar kewirausahaan dan Dunia Usaha/Dunia Industri (DU/DI), perlu adanya upaya untuk memadukan kemampuan entrepreneurship mahasiswa dari tiga konsentrasi yang ada di Pendidikan Ekonomi dengan harapan dapat meningkatkan entrepreneur skill mahasiswa. Praktik Kewirausahaan Terpadu merupakan suatu kegiatan pembelajaran praktik kewirausahaan yang terwadahi dalam mata kuliah Kewirausahaan lanjutan yang dalam pelaksanaannya dibantu oleh praktisi DU/DI bersama EEL (Entrepreneurship Education Laboratory) melalui divisi-divisi terkait yang ada di dalamnya. Dengan demikian tercipta integrated multidiciplinary perspective, yang melibatkan tiga komponen, yaitu mahasiswa dengan berbagai BKK, DU/DI, dan EEL.
Untuk membangun manusia yang berjiwa kreatif, inovatif, sportif serta berjiwa wirausaha, memerlukan pengkondisian lingkungan dan sarana prasarana yang menunjang tumbuhnya jiwa tersebut. Dari berbagai sarana prasarana pendidikan dan pembelajaran, laboratorium sebagai kelengkapan akademik dapat digunakan sebagai penunjang pendidikan dan pembelajaran yang dapat mengkondisikan para peserta didik untuk menjadi manusia kreatif, inovatif, sportif dan berjiwa wirausaha.

Entrepreneurship Education Laboratory (EEL) merupakan laboratorium Entrepreneurship terpadu yang diharapkan dapat menunjang kegiatan pembelajaran Kewirausahaan baik teori maupun praktik sebagai inisiasi untuk menumbuhkembangkan jiwa wirausaha yang berkarakter kuat dan cerdas di Prodi Pendidikan Ekonomi, PIPS, FKIP, UNS. Mata kuliah kewirausahaan lanjutan diperlukan bagi mahasiswa Program Studi Pendidikan Ekonomi sebagai inisiasi untuk melatih keterampilan dan menghasilkan calon wirausaha muda yang berkarakter kuat dan cerdas.

Kegiatan penelitian ini merupakan uji coba perkuliahan kewirausahaan lanjutan yang dirancang untuk membekali mahasiswa dengan keahlian praktikum yang diawali dengan tahapan eksplorasi materi perkuliahan, pengembangan ide usaha, pembuatan perencanana usaha dan pematangan perencanaan usaha dengan melakukan observasi lapangan di usaha kecil dan menengah (UKM)/DUDI yang telah sukses menjalankan usaha. Tujuan observasi lapangan ini untuk mempelajari bagaimana mendirikan, memulai dan menjalankan usaha dengan baik dan sukses menumbuhkembangkan usahanya. Hasil kegiatan observasi lapangan adalah penyempurnaan rencana usaha yang akan dikompetisikan untuk mendapatkan dana kompetitif, dari Prodi, Fakultas, Universitas, DU/ DI, atau lembaga lain untuk membuka usaha baru. Menjalankan usaha baru merupakan pemberian pengalaman praktik kepada mahasiswa yang akan dilanjutkan dengan membuat laporan usaha serta presentasi usaha yang telah dijalankan. Kegiatan akhir dalam program pembelajaran 
praktik kewirausahaan adalah pameran produk usaha.

Kegiatan pembelajaran praktik kewirausahaan yang tertuang pada mata kuliah kewirausahaan lanjutan ini dilaksanakan sebagai bentuk menumbuhkembangkan jiwa wirausaha dan menggembleng mahasiswa untuk menjadi manusia yang berkarakter kuat berbasis kewirausahaan. EEL sebagai satuan penunjang yang akan mendukung proses penanaman, penumbuhan dan pengembangan jiwa wirausaha yang berkarakter di Prodi Pendidikan Ekonomi, PIPS, FKIP, UNS. Kerjasama dengan EEL diharapkan dapat membantu menunjang kelancaran program pembelajaran kewirausahaan di Prodi Pendidikan Ekonomi, PIPS, FKIP, UNS.

Pembelajaran kewirausahaan lanjutan yang dilakukan secara terpadu ini dirancang menjadi salah satu syarat dan aspek penentu bagi keberhasilan mahasiswa dalam menyelesaikan pendidikan di Prodi Pendidikan Ekonomi, PIPS, FKIP, UNS. Dengan demikian, Praktik kewirausahaan terpadu merupakan suatu bentuk penyelenggaraan pendidikan keterampilan kewirausahaan dan pendidikan karakter sekaligus memadukan secara sistematis dan sinkron antara pembelajaran praktik yang diperoleh langsung di laboratorium dan pembelajaran di lapangan dengan prinsip integrated multidiciplinary perspective.

Penelitian ini bertujuan untuk mengetahui hal-hal seperti berikut. (1) Keefektifan rancangan model laboratorium entrepreneurship terpadu, setelah diuji coba secara terbatas. (2) Desain empirik hasil pengembangan setelah dilakukan evaluasi dan revisi model. (3) Hasil uji coba model secara lebih luas.

Hasil dari penelitian ini diharapkan seperti berikut. (1) Memberikan sumbangan untuk perbaikan mutu pembelajaran kewirausahaan khususnya di Prodi Pendidikan Ekonomi. (2) Memberikan sumbangan pemikiran untuk pengembangan ilmu khususnya ilmu kewirausahaan. (3) Berpartisipasi dalam program pemerintah dalam mengembangkan budaya kewirausahaan di perguruan tinggi.

\section{METODE}

Studi ini berada pada bingkai penelitian dan pengembangan (Research and Development) (Borg \& Gall, 1989). Tujuan utama dari penelitian dan pengembangan ( $R \& D$ ) ini bukanlah untuk memformulasi atau menguji teori tetapi mengembangkan produk-produk yang efektif untuk kepentingan pendidikan dan pengajaran yang digunakan di sekolah. Produk-produk yang dihasilkan dapat digunakan sebagai materi pelatihan, materi pembelajaran, materi media pembelajaran, dan manajemen pendidikan (Gay,1987).

Penelitian ini dilakukan dua tahap. Pada tahap pertama dilakukan eksplorasi lapangan untuk mengetahui kebutuhan laboratorium entrepreneurship di prodi pendidikan ekonomi dan penentuan contoh model laboratorium entrepreneurship terpadu, dilanjutkan dengan menyusun abstraksi model laboratorium entrepreneurship terpadu, dan prototipe model laboratorium entrepreneurship terpadu. Pengumpulan data survei lapangan dan analisis data memakai pendekatan kualitatif. Hasil penelitian eksploratif, kemudian disusun rekonstruksi faktor dan interrelasi faktor yang mendukung pengembangan laboratorium entrepreneurship terpadu di Prodi Pendidikan Ekonomi.

Pada bagian penelitian pengembangan, didahului dengan penyusunan draft (model konseptual), yaitu merupakan model pembelajaran hasil abstraksi dan konstruksi berdasarkan eksplorasi lapangan yang telah divalidasi secara teoretik melalui diskusi, justifikasi ahli (expert judgment), konsultasi yang melibatkan ahli pendidikan, praktisi pendidikan kewirausahaan, lembaga pendidikan kewirausahaan, pengusaha UKM.

Rumusan hasil perbaikan dan modifikasi dalam seminar/lokakarya pada penelitian tahap pertama, selanjutnya dipakai untuk uji coba terbatas (selama satu semester) untuk mengkaji kelayakan program dan kemungkinan implementasinya di lapangan. Dari hasil ujicoba terbatas, disusunlah pengembangan model yang merupakan hasil evaluasi dan revisi produk yang sudah disempurnakan dengan berbagai persyaratan pelaksanaan program praktik ke- 
wirausahaan. Perhatian khusus diberikan dalam segi materi ajar dan strategi pembelajaran, yang disusun berdasarkan produk pengembangan penelitian tahap pertama, yaitu perbaikan dan penyempurnaan draft buku pedoman praktik kewirausahaan dan desain pembelajaran praktik kewirausahaan.

Populasi penelitian adalah mahasiswa semester tiga (3), yang mengambil mata kuliah kewirausahaan sebanyak 150 orang yang terbagi dalam 30 kelompok usaha. Uji coba model secara terbatas dilaksanakan dengan memilih tiga kelompok usaha terbaik (juara I, II, dan III) masing-masing beranggotakan 5 orang mahasiswa yang sudah mengikuti kompetisi usaha pada akhir perkuliahan. Teknik pengambilan sampel pada uji coba lebih luas berdasarkan faktor keberadaan dan kesediaan mahasiswa untuk dijadikan sampel, mengingat mata kuliah lanjutan kewirausahaan belum tercantum dalam kurikulum dan bersamaan waktu mahasiswa persiapan ujian semester. Sampel diambil sepertiga dari 30 kelompok usaha mahasiswa yang telah mengambil mata kuliah kewirausahaan, yaitu 10 kelompok mahasiswa dari BKK PAP, PAkt, dan PTN. Prosedur penelitian pengembangan dituangkan dalam Gambar 1.

\section{HASIL DAN PEMBAHASAN}

\section{Hasil Studi Eksploratif}

Hasil studi eksploratif menunjukkan bahwa pelaksanaan pembelajaran mata kuliah kewirausahaan di tiga BKK Prodi Pendidian Ekonomi belum terintegrasi dalam satu program pembelajaran praktik. Silabus, strategi pembelajaran, model, media, dan perangkat pembelajaran yang digunakan tergantung inovasi dari setiap dosen pengampu. Pembelajaran praktik masih kurang.

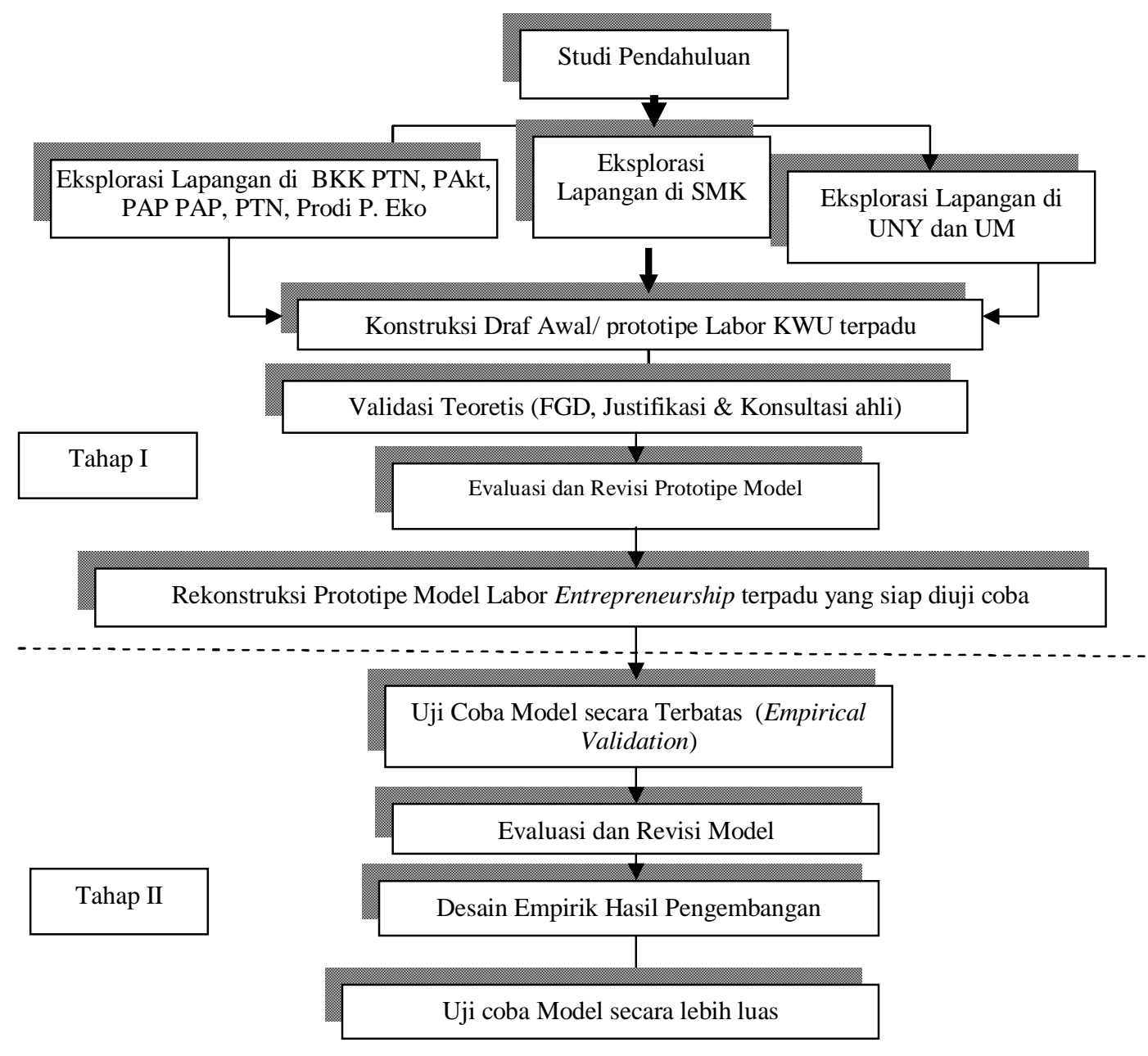

Gambar 1. Proses Pengembangan Model Laboratorium Entrepreneurship Terpadu Prodi Pendidikan Ekonomi, PIPS, FKIP, UNS 
Mata kuliah Kewirausahaan merupakan mata kuliah umum yang wajib diambil oleh semua mahasiswa UNS sebagai inisiasi untuk menumbuhkan jiwa wirausaha. Pada Prodi Pendidikan Ekonomi, kewirausahaan dapat dikatakan sebagai identitas program studi, oleh karena itu perlu dikembangkan ke arah lebih banyak praktik yang dituangkan dalam mata kuliah kewirausahaan lanjutan.

Pelaksanaan perkuliahan praktik di masing-masing BKK Prodi Pendidikan Ekonomi, dilaksanakan di laboratorium, yaitu laboratorium "Bank Mini" untuk praktik perbankan BKK PAk, laboratorium "Tania Mart" untuk praktik bisnis pemasaran BKK PTN, laboratorium "Mini Office" untuk praktik perkantoran BKK PAP. Khusus untuk praktik kewirausahaan di Prodi Pendidikan Ekonomi belum memiliki laboratorium tersendiri.

Perkembangan ilmu pengetahuan dan teknologi menuntut perbaikan kualitas pembelajaran dan perubahan strategi penyediaan sarana dan prasarana pembelajaran. Dengan demikian, lembaga pendidikan dan tenaga kependidikan (LPTK) memiliki kewajiban untuk menyediakan beragam sumber belajar sebagai bagian terpadu dari proses pembelajaran. Selanjutnya disebutkan bahwa keluasan ruang gerak mahasiswa untuk berinteraksi, menuntut adanya ruang kelas/laboratorium/bengkel yang lebih luas dan fleksibel (Kementerian Pendidikan Nasional, 2010).

Adanya laboratorium tidak bisa dipisahkan dalam kegiatan pembelajaran karena laboratorium dalam Webster's New World Dictionary (1991:753), "A place where theories, technique, and methods, as in education or social studies, are tested, analyzed, demonstrated, etc." Dengan demikian, ketersediaan laboratorium kewirausahaan diperlukan sebagai sarana atau tempat yang bisa digunakan untuk menganalisis, menguji, menyiapkan, mendemonstrasikan atau mempraktikkan kegiatan usaha.

Fakultas Ekonomi, UNY memiliki Laboratorium Kewirausahaan yang berupa "EEC (Entrepreneurship Education Centre) Mart" yang menjadi wahana praktik menjual barang. Bisnis Center (EEC Mart) sebagai grosir bagi para mahasiswa untuk melakukan kegiatan praktik menjual barang di Bisnis Center (BC) dengan model praktik individual.

Pelaksanaan praktik Kewirausahaan di FE UM, ditunjang oleh Creative Center (CC). $\mathrm{CC}$ merupakan laboratorium bersama sebagai penunjang akademik mata kuliah kewirausahaan. Di Laboratorium CC ini para mahasiswa yang berminat untuk mendirikan usaha dan mengembangkan ide usaha dibimbing dan diarahkan. CC juga memiliki kelompok komunitas bisnis yang terdiri dari para mahasiswa dan dosen yang memiliki usaha baik yang baru tumbuh maupun berkembang untuk saling bertukar pengalaman dan pengetahuan.

Hasil observasi di beberapa SMK di Kota Surakarta, pembelajaran praktik kewirausahaan identik dengan pembelajaran menjual barang. Hal ini terjadi karena praktik kewirausahaan terpadu yang diselenggarakan di SMK menekankan pada praktik menjual dan memasarkan barang yang diambil dari Business Center.

Dari hasil studi eksploratif dipilih model yang cocok dan memenuhi kriteria keterpaduan pelaksanaan praktik kewirausahaan di Prodi Pendidikan Ekonomi, yaitu dengan prinsip: (1) learning by doing; (2) multidisciplinary perspectives; (3) experience-based learning; (4) the making of judgements underpressures; (5) flexible learning situations; and (6) the use of practicioners (Henderson \& Robertson, 1999: 240). Model proses pembelajaran praktik kewirausahaan yang dirancang merupakan modifikasi dari model pembelajaran praktik pendirian usaha baru di FE UNY.

\section{Uji Coba Terbatas}

Pelaksanaan perkuliahan KWU dengan multidisciplinaryperspectives yang mengutamakan keberagaman pengetahuan yang dimiliki para mahasiswa dari berbagai bidang keahlian akan dapat menciptakan sinergi yang kuat dan lengkap dalam membuat dan menyusun perencanaan usaha yang inovatif. Pelaksanaan pembelajaran kewirausahaan praktik kewirausahaan dalam uji coba terbatas mengacu pada prinsipprinsip Henderson \& Robertson (1999) dan modifikasi model pembelajaran praktik FE, UNY. 
Rancangan/prototipe model labor entrepreneurship terpadu disusun dan diujicobakan secara terbatas selama 4 bulan terhadap tiga kelompok mahasiswa terpilih, yang terdiri dari berbagai disiplin ilmu (BKK) melaksanakan praktik kewirausahaan dengan langkah-langkah sebagai berikut.

- Membentuk tim kerja kelompok baru yang beranggotakan mahasiswa dari tiga BKK di Prodi Pendidikan Ekonomi, dengan jumlah anggota maksimal lima orang. Pada tahapan ini, tiga kelompok mahasiswa menemukan ide membentuk Kreativitas Wong Pendidikan Ekonomi yang kemudian disingkat dengan KONDE sebagai label nama perusahaan payung.

- Mengembangkan ide usaha dengan melakukan analisis SWOT untuk menentukan strategi pengembangan usaha. Muncul tiga (3) ide usaha, yaitu produksi tas FKIP, kemeja putih FKIP, dan kaos oblong pendidikan ekonomi. Ke-3 usaha tersebut bernaung di bawah "KONDE PRODUCTION".

- Menyusun perencanaan usaha. Pada tahap ini mahasiswa banyak berkonsultasi dengan tim kreatif yang berada di salah satu unit EEL yang memberikan masukan tentang segala sesuatu yang berhubungan dengan usaha yang akan dilakukan.

- Melakukan observasi lapangan ke tempat pengusaha sukses, yaitu di PT DAN LIRIS SUKOHARJO. Pemilihan tempat didasarkan pada asumsi bahwa PT DAN LIRIS memproduksi ketiga jenis produk yang akan dikembangkan oleh mahasiswa, sehingga akan terjadi efisiensi biaya dan waktu.

- Melakukan refleksi, konsultasi, evaluasi, dan penyempurnaan rencana usaha. Berdasarkan masukan dan arahan dari dosen pembimbing serta hasil observasi mahasiswa secara bersama-sama melakukan refleksi, konsultasi dan evaluasi atas rencana usaha yang telah disusun sebelumnya sehingga pada akhirnya diharapkan dapat menghasilkan rencana usaha yang lebih sempurna.

- Melakukan presentasi rencana usaha di depan calon penyandang dana. Tahapan ini dilakukan untuk mengkompetisikan hasil ren- cana usaha yang telah disusun oleh mahasiswa, sekaligus penentuan pemberian subsidi produksi. Hasil kompetisi menetapkan bahwa yang berhak mendapat juara pertama adalah kelompok usaha kemeja putih FKIP, juara ke-2 kelompok kaos pendidikan ekonomi, dan disusul oleh kelompok usaha tas konde.

- Melakukan persiapan pembukaan usaha baru telah dilakukan mahasiswa dengan memproduksi usaha masing-masing. Ketika melakukan proses produksi, kelompok tas Konde mengalami kesulitan mencari bahan baku sesuai yang diinginkan karena konveksi yang disurvei sebelumnya tidak dapat menyediakan bahan seperti yang diharapkan dengan alasan kenaikan harga bahan. Hal ini juga dialami oleh kelompok kaos dan baju putih.

- Melakukan launching usaha baru dan membuat laporan cash flow mingguan. Tahapan ini dilakukan selama dua hari di lingkungan kampus dengan harapan dapat lebih dikenal oleh calon pengguna/konsumen. Setelah kegiatan launching produk, kelompok usaha menyusun laporan cash flow atas kegiatan yang sudah dilakukan.

- Pada tahap presentasi usaha, mahasiswa melakukan pemaparan hasil kegiatan penjualan/pemasaran produk yang telah dilakukan selama dua minggu. Pada kegiatan ini kelompok kemeja putih telah berhasil menjual produk sebanyak 10 kemeja, tas kanvas konde terjual 15 buah, dan kaos oblong pendidikan ekonomi terjual 12 potong.

- Melaksanakan eksposisi produk usaha yang akan dikembangkan melalui gelar produk di lingkungan FKIP UNS dengan tujuan untuk lebih mengenalkan produk yang dibuat oleh mahasiswa serta lebih mengenalkan KONDE PRODUCTION di lingkungan FKIP.

\section{Evaluasi dan Revisi}

Evaluasi dan revisi kegiatan uji coba menghasilkan banyak masukan baik dari mahasiswa, dosen pembimbing kewirausahaan, maupun dari BKK PAP, PTN, dan PAK. Beberapa masukan sebagai berikut. (1) Pada tahapan membentuk tim kerja kelompok dirasakan kurang 
adanya koordinasi antara tim peneliti dengan mahasiswa sehingga terjadi ketidaksamaan persepsi di antara tim peneliti dan mahasiswa. (2) Pada kelompok usaha yang berasal dari latar belakang bidang keahlian (BKK) yang berbeda terjadi kesulitan ketika menentukan waktu untuk melakukan diskusi. (3) Ketika menyusun perencanaan usaha, mahasiswa kurang intensif melakukan konsultasi dengan dosen pembimbing sehingga belum maksimal dalam menyusun rencana usaha. (4) Pemilihan tempat observasi kurang sesuai dengan kebutuhan, mahasiswa kurang mendapatkan pengetahuan yang akan dipraktikan dalam menyusun rencana usaha maupun menjalankannya. (5) Pada tahapan kompetisi, kelompok usaha mahasiswa kurang mendapat informasi secara jelas dan rinci bahwa rencana usaha ini akan dikompetisikan sehingga kelompok yang "tidak menang" merasa kurang puas karena merasa bahwa semua adalah ide besar bersama. (6) Pada tahapan pro- duksi ke tiga kelompok usaha mengalami permasalahan yang hampir sama yaitu mengalami kesulitan mencari bahan baku yang sesuai baik jenis maupun harga karena terjadi kenaikan harga. (7) Pada tahap launching usaha baru, kelompok usaha mahasiswa merasakan kekurangan waktu yang ditentukan selama 2 hari di lingkungan kampus. Setelah melaksanakan launching produk, kelompok usaha diwajibkan menyusun laporan cash flow atas kegiatan yang sudah dilakukan. Hal ini juga berpengaruh pada tahapan penjualan/ pemasaran produk, sehingga kuantitas penjualan kurang dan segmen pasar kurang luas. (8) Harga barang relatif masih mahal di kalangan mahasiswa karena kelompok usaha belum bisa memproduksi barang dalam jumlah besar sehingga menyebabkan ongkos produksi tidak bisa ditekan.

Secara keseluruhan kegiatan pembelajaran kewirausahaan di Pendidikan Ekonomi dapat dilihat pada Gambar 2.

\section{PENGEMBANGAN MODEL PRAKTIK ENTREPRENEURSHIP TERPADU}

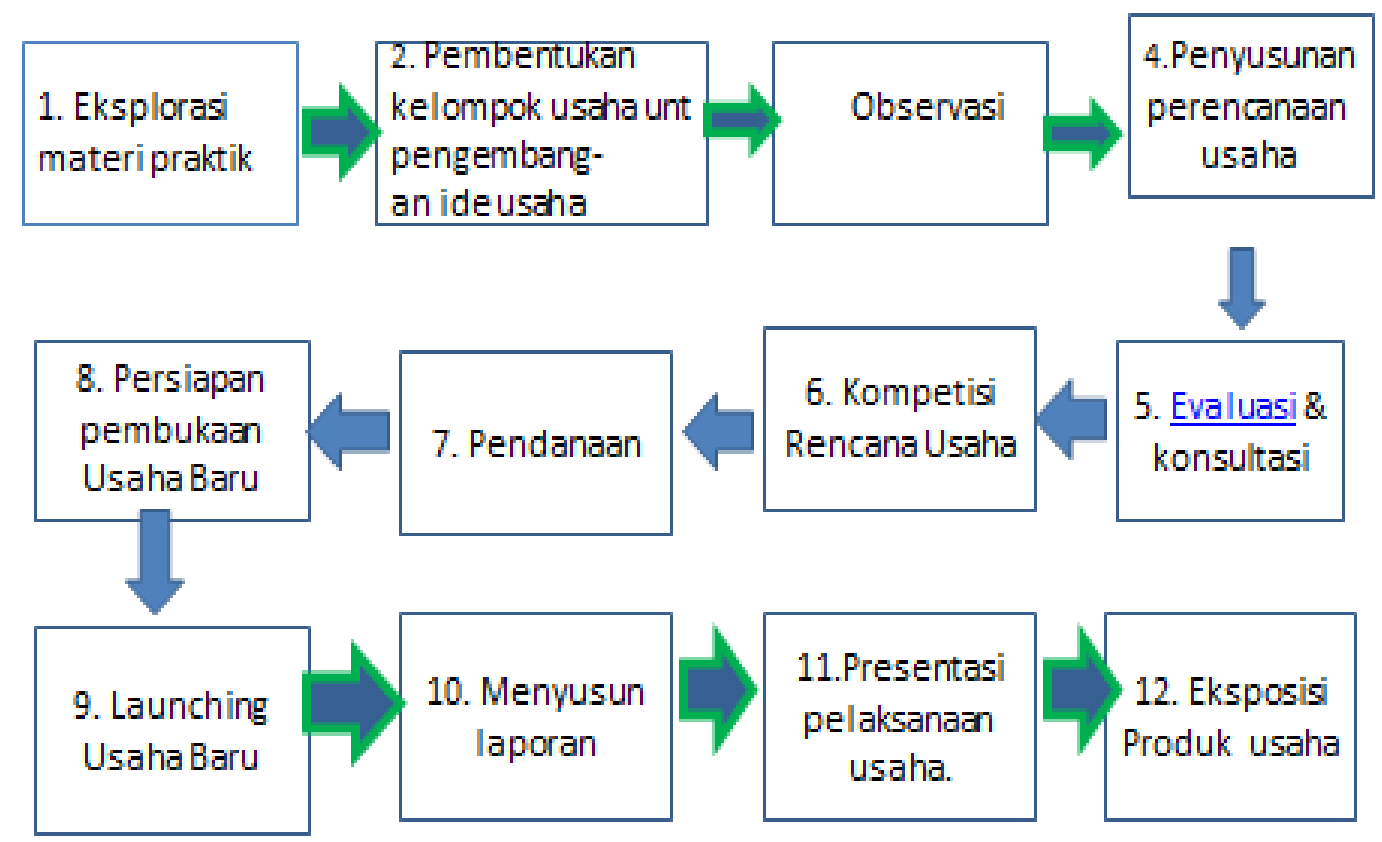

Gambar 2. Model Pembelajaran Praktik Kewirausahaan Terpadu 


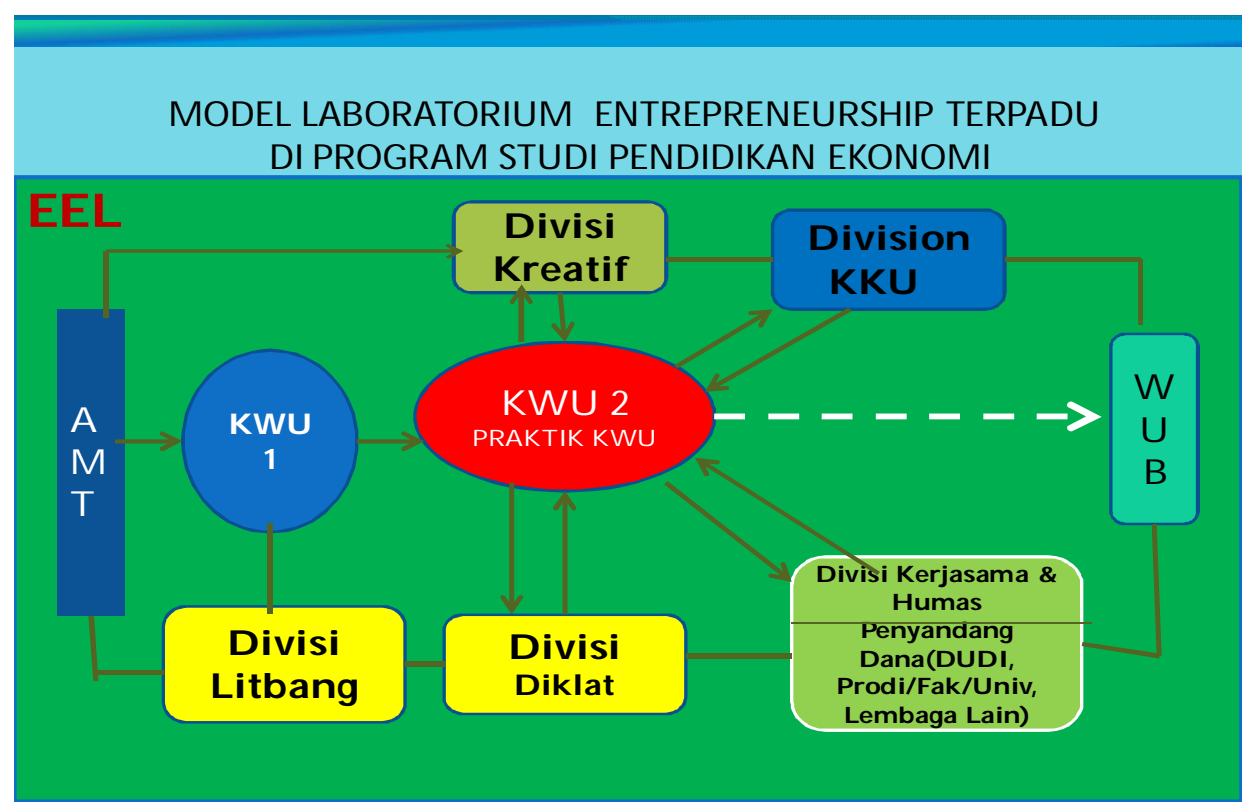

Gambar 3. Model Laboratorium Kewirausahaan Terpadu di Prodi Pendidikan Ekonomi FKIP UNS

\section{Desain Empirik Model Pengembangan}

Berdasarkan hasil uji coba terbatas dan evaluasi serta revisi model, diperoleh suatu desain empirik model pengembangan laboratorium terpadu yang terwadahi dalam Entrepreneurship Education Laboratory (EEL), yang di dalamnya terdiri dari beberapa divisi yaitu divisi creative (Creative Centre), divisi penelitian dan pengembangan (Litbang), divisi kerjasama, divisi pendidikan dan pelatihan (Diklat), divisi klinik konsultasi usaha (KKU).

Peranan perguruan tinggi (PT) adalah menyediakan suatu wadah yang memberikan kesempatan mahasiswa untuk memulia usaha sejak masa kuliah sangatlah penting (Galus, 2013). EEL diharapkan dapat dijadikan wadah bagi mahasiswa Prodi Pendidikan Ekonomi untuk memotivasi dan mengembangkan kreativitas dan inovasi sebagai calon wirausaha muda dan calon pendidik yang berjiwa entrepreneur. Galus menyebutkan bahwa yang paling penting adalah bagaimana peranan PT dalam hal memotivasi mahasiswa untuk masuk di dalam wadah tersebut.

Masing-masing divisi diharapkan dapat bersinergi dalam mengembangkan labotarorium kewirausahaan ini sesuai dengan tugasnya. Adapun tugas dari masing-masing divisi adalah divisi kreatif (Creatice Center). Divisi ini ber- tugas membimbing mahasiswa untuk mengembangkan kreatifitas dengan berbagai cara, memperbaiki, memodifikasi, mengembangkan sesuatu yang sudah ada yang pada akhirnya akan menghasilkan karya-karya inovatif. Pada dasarnya siapapun yang memiliki jiwa kewirausahaan akan menjadi agen perubahan yang mampu dan sanggup mentransformasi sumberdaya yang ada di sekitarnya untuk memperoleh nilai tambah yang menguntungkan, baik secara ekonomi maupun non-ekonomi (Coulter, 2003).

Berdasarkan hasil diskusi dengan kelompok terfokus, diputuskan personal yang akan bertanggung jawab untuk memimpin EEL yang terbagi dalam divisi penelitian dan pengembangan (Litbang), divisi kerjasama dan hubungan masyarakat, divisi klinik konsultasi usaha (KKU), divisi pendidikan dan pelatihan (Diklat), dan divisi kreatif. Divisi Litbang bertugas untuk melakukan penelitian dan pengembangan sumber daya yang ada serta membuat programprogram yang mampu mendorong terciptanya calon-calon wirausaha baru di Prodi Pendidikan Ekonomi pada khususnya dan FKIP pada umumnya. Divisi kerjasama dan Humas, bertugas untuk menjalin dan mengembangkan kerjasama dengan berbagai pihak dalam rangka membesarkan dan memajukan EEL. 
Kerja sama di sini dapat dilakukan antara lain dengan alumni, guru, DUDI, dan para pemangku kepentingan lainnya. Divisi klinik konsultasi usaha (KKU), bertugas memberikan bimbingan dan konsultasi kepada para mahasiswa calon wirausaha baru maupun para mahasiswa yang sedang belajar berwirausaha, memberikan arahan dan motivasi agar usahanya berjalan lancar dan semakin berkembang. Divisi pendidikan dan pelatihan (Diklat), bertanggung jawab untuk mengadakan kegiatan pendidikan dan pelatihan kewirausahaan, baik untuk dosen, mahasiswa maupun masyarakat yang membutuhkan. Divisi kreatif bertugas membimbing dan mengembangkan kreativitas mahasiswa serta membantu mempublikasikan dan memasarkan hasil kreatifitas mahasiswa.

Adapun model laboratorium kewirausahaan terpadu yang dikembangkan di Program Studi Pendidikan Ekonomi, FKIP, UNS ditunjukkan pada Gambar 3.

\section{Uji Coba Model lebih Luas}

Pada tahap uji coba lebih luas, tahapan kegiatan yang dilakukan sama dengan tahapan kegiatan pada uji coba terbatas dan diterapkan pada mahasiswa yang sudah mengikuti mata kuliah kewirausahaan.

- Membentuk 10 kelompok mahasiswa yang berlatar belakang Pendidikan Ekonomi Akuntansi, Pendidikan Administrasi Perkantoran dan Pendidikan Tata Niaga. Tiap-tiap kelompok beranggotakan 3 sampai dengan 5 orang.

- Pada tahap kegiatan pengembangan ide usaha dilakukan analisis SWOT untuk menentukan strategi pengembangan usaha. Pada kelompok ini berkembang bermacam-macam ide yang dimiliki oleh mahasiswa sebagai calon wirausaha baru, antara lain kalender, cendera mata, catering, recycle jeans, C\&R KONDE, ballpoint KONDE, mouse pad KONDE, Vegechoco KONDE, softcase laptop.

- Menyusun perencanaan usaha, mahasiswa banyak berkonsultasi dengan tim Kreatif yang merupakan salah satu unit dari EEL. Tim ini memberi masukan kepada mahasiswa tentang segala sesuatu yang berhubungan dengan usaha yang akan dilakukan oleh masing-masing kelompok.

- Melakukan observasi lapangan di UKM yang sejenis dengan usaha yang akan mereka lakukan. Pada tahapan ini sebagian besar kelompok melakukan observasi ke Night Market Ngarsopuro dimana tempat ini banyak berkumpul pengusaha UMKM yang menjual produknya, toko penyedia bahan baku, dan lain-lain.

- Melakukan refleksi,konsultasi, evaluasi, dan penyempurnaan Rencana Usaha berdasarkan masukan dan arahan dari dosen pembimbing serta hasil observasi lapangan, diharapkan dapat menghasilkan rencana usaha yang lebih sempurna.

- Mengadakan Lomba Rencana Usaha. Masing-masing kelompok usaha mempresentasikan rencana usahanya untuk memilih dan menentukan kelompok-kelompok usaha terbaik sekaligus pemberian subsidi produksi. Berdasar presentasi mahasiswa, maka juri menetapkan bahwa semua kelompok berhak mendapat stimulan dana untuk produksi, sedangkan kelompok Catering KONDE, Mouse pad KONDE dan So'UNS merupakan tiga rencana usaha yang dipandang lebih bagus dibanding rencana usaha lainnya.

- Melakukan persiapan pembukaan usaha baru telah dilakukan mahasiswa dengan memproduksi usaha masing-masing.

- Mulai melakukan kegiatan produksi.

- Melakukan launching usaha baru dan membuat laporan cash flow mingguan.

- Presentasi usaha. Mahasiswa kelompok usaha mempresentasikan/melaporkan pelaksanaan usaha di depan para dosen pembimbing.

- Melaksanakan eksposisi produk usaha yang akan dikembangkan melalui gelar produk di lingkungan FKIP UNS.

Hasil uji coba secara lebih luas dituangkan dalam Tabel 1. 
Tabel 1. Hasil Uji Coba lebih Luas

\begin{tabular}{cllll}
\hline \multicolumn{2}{l}{ Tahapan } & Baik $\mathbf{( \% )}$ & Sedang $(\%)$ & Kurang $(\%)$ \\
\hline 1. & Eksposisi materi Kwu & 40 & 32 & 28 \\
2. & Pembentukan kelompok & 58 & 40 & 2 \\
3. & Observasi ke UKM sejenis & 62 & 30 & 8 \\
4. & Penyusunan rencana usaha & 63 & 20 & 17 \\
5. & Evaluasi dan Revisi & 40 & 32 & 28 \\
6. & Kompetisi rencana usaha & 58 & 40 & 2 \\
7. & Pendanaan & 52 & 20 & 28 \\
8. & Persiapan usaha baru & 40 & 32 & 28 \\
9. & Launching usaha baru & 58 & 40 & 2 \\
10. & Presentasi hasil usaha & 62 & 30 & 8 \\
11. & Eksposisi hasil usaha & 58 & 40 & 2 \\
\hline
\end{tabular}

Tabel menunjukkan pada tahapan-tahapan kegiatan praktik kewirausahaan, besaran persentase menunjukkan trend baik pada semua tahapan. Dengan demikian, ia juga menunjukkan bahwa model ini efektif untuk menumbuhkembangkan jiwa wirausaha meningkatnya kreativitas ide dan minat serta semangat untuk berwirausaha.

\section{PENUTUP}

Berdasar hasil penelitian dapat disimpulkan bahwa pelaksanaan perkuliahan KWU dengan Multidisciplinary Perspectives yang mengutamakan keberagaman pengetahuan yang dimiliki para mahasiswa dari berbagai bidang keahlian akan dapat menciptakan sinergi yang kuat dan lengkap dalam membuat dan menyusun perencanaan usaha yang inovatif.

Mata kuliah Kewirausahaan lanjutan sebagai mata kuliah praktik terbukti dapat menjadi inisiasi munculnya motivasi, semangat, kreativitas dan inovasi yang akan menghasilkan calon wirausaha muda yang berkarakter kuat dan cerdas. Oleh karena itu, akan dijadikan mata kuliah wajib bagi mahasiswa Prodi Pendidikan Ekonomi.

Hasil uji coba terbatas menyepakati pembentukan Kreatifitas wOng peNDidikan Ekonomi yang kemudian disingkat dengan KONDE sebagai label nama perusahaan. Pada kelompok ini ada 3 ide usaha yang muncul yaitu produksi tas FKIP, Kemeja putih FKIP dan kaos pendidikan ekonomi. Ke-3 usaha tersebut bernaung di bawah “KONDE PRODUCTION”.
Evaluasi dan revisi model, perlu koordinasi yang lebih baik antara tim peneliti, dosen pembimbing/pengampu mata kuliah kewirausahaan dan mahasiswa agar terjadi persamaan persepsi yang akan memperlancar kegiatan. Intensitas mahasiswa dalam bimbingan dengan dosen pembimbing dan divisi terkait akan bisa ditingkatkan dengan menyediakan waktu selama satu semester dan menyiapkan instrumen penilaian bagi mahasiswa serta kesiapan/keaktifan dosen pembimbing beserta divisi terkait untuk kegiatan pelayanan. Perlu memilih objek observasi usaha kecil dan menengah yang sesuai dengan ide usaha yang akan dikembangkan oleh kelompok mahasiswa.

Hasil uji coba lebih luas, semua kelompok uji coba telah menunjukkan keseriusan, keaktifan, dan kreatifitas. Pada tahapan-tahapan kegiatan praktik kewirausahaan, besaran yang ditunjukkan dalam tabel menunjukkan trend baik pada semua tahapan. Dengan demikian, menunjukkan bahwa model ini efektif untuk menumbuhkembangkan jiwa wirausaha, meningkatnya kreativitas ide dan minat, serta semangat untuk berwirausaha.

\section{UCAPAN TERIMA KASIH}

Ucapan terimakasih disampaikan kepada Dekan, FE, UNY Dr. Sugiharsono, M.Si bersama jajaran Pembantu Dekan, Prof. Dr. Aliyah Rasyid Baswedan selaku Ketua EEC, dan ibu Endang Mulyani, M.Si. sekretaris EEC, bersama Staf Laboratorium Kewirausahaan, Bp. Dekan FE, UM, Prof. Dr. Ery Trijatmiko, 
R.W.W. MA., M.Si. berserta jajaran pembantu dekan, dan ketua Divisi kreatif/kewirausahaan Dr. Wahyu Wibowo, A.Md., SE.,M.M. yang telah bersedia sharing knowledge and experience dalam membantu kami untuk mewujudkan laboratorium entrepreneurship terpadu Program Studi Pendidikan Ekonomi, PIPS, FKIP, UNS. Tidak lupa terimakasih kami ucapkan kepada LPPM UNS yang telah memfasilitasi penelitian ini.

\section{DAFTAR PUSTAKA}

Borg, W.R. \& Gall, M.D. 1989. Educational Research: An Introduction. London: Longman, Inc.

Coulter, M. 2003. Entrepreneurship in Action. New Yersey: Prentice Hall.

Galus, Ben Senang, 2013. Relevansi Pendidikan Kewirausahaan di Perguruan Tinggi. dari http://www.pendidikan_diy.go.id/dinas_v4/?. Diunduh 20 Mei 2014.
Gay,L.R.1987. Educational Research: Competencies for Analysis and Application. Colombus, OH: Charles E Merill.

Henderson, R \& M. Robertson. 1999. "Who Want to be an Entrpreneur? Young Adult Attitudes to Entrpreneurships as a Career". Education \& Training Journal. Vol 41, 4/5, hlm 236-246.

Kementerian Pendidikan Nasional, Balitbang, Puskur. 2010. Pengembangan Pendidikan Budaya dan Karakter Bangsa. Jakarta: Kemendiknas, Balitbang, Puskur.

Webster. 1991. Webster`s New World Dictionary of American English: Third College Edition. New York: Prentice Hall General Reference 15 Columbus Circle. 